\title{
"NATURE'S STOMACH": \\ EMERSON, WHITMAN, AND THE POETICS OF DIGESTION
}

\author{
Sean Ross MeEhan
}

\begin{abstract}
American life storms about us daily, and is slow to find a tongue. This contemporary insight is transubstantiation, the conversion of daily bread into the holiest symbols; and every man would be a poet, if his intellectual digestion were perfect. - Ralph Waldo Emerson

. . . Nature's stomach is fully strong enough not only to digest morbific matter always presented, not to be turn'd aside, and perhaps, indeed, intuitively gravitating thitherbut even to change such contributions into nutriment for highest use and life-so American democracy's.

-Walt Whitman
\end{abstract}

\section{EATING EMERSON}

LATER IN WALT WhitMAN's LIFE, glancing backward and forward in his prose, as he was accustomed to do, the poet addressed what was already a vexed matter, the question concerning the influence of Ralph Waldo Emerson, the author he once called "Master." Writing in "Emerson's Books (The Shadows of Them)," a piece originally published in the May 1880 Boston Literary World and reprinted in "Notes Left Over" in Specimen Days and Collect two years later, shortly after Emerson's death, Whitman admits that "years ago...like most youngsters" he had "a touch (though it came late, and was only on the surface) of Emersonon-the-brain." As Whitman makes clear in the vigorous criticism of Emerson's "cold and bloodless intellectuality" preceding this admission, however, the tinge of Emersonian intellect earlier in his own blood had long been purged from his system, the better for his own health and the future of American readers ( $P W, 2: 516)$. In propagating this criticism of Emerson, a criticism that Whitman biographer Jerome Loving has called "grossly and unconscionably unfair," we note that Whitman turns to the language of food and physiology. "First, then, these pages are perhaps too perfect, too concentrated. (How good, for instance, is good butter, good sugar. But to be eating nothing but sugar and butter all the time! even if ever so good.)" (PW, 2:515). Whitman culminates his metaphor of eating Emerson's writing by extending the figure to 
its digestive conclusion: "Suppose these books becoming absorb'd, the permanent chyle of American general and particular character - what a well-wash'd and grammatical, but bloodless and helpless, race we should turn out!" (PW, 2:516). "Chyle," as Orson Fowler's Physiology, Animal and Mental (1847) defines the term, is a glandular secretion and key component in the digestive process in which food moves from stomach to intestines to absorption into the circulation of blood: "a half-liquid grayish substance, closely resembling milk in appearance, laden with fibrine . . . and other substances required to support life." ${ }^{3}$ Emerson's ideas might taste sweet to a refined few or at a younger point in one's life, Whitman suggests, but on a closer inspection, Emerson's books can't provide the substantial nutriment required to fiber the lifeblood of American character.

What Whitman goes on to name "Emersonianism," in this context of physiology and digestion, sounds something like an intestinal ailment or a rare blood disease. John Burroughs, in his own critical reassessment of Emerson that was coached by Whitman and published several years earlier, would also turn to physiological figures. Emerson, Burroughs asserts, is a brain without bowels, "deficient in viscera, in moral and intellectual stomach": "his is, on the whole, a bloodless kind of poetry. It suggests the pale gray matter of the cerebrum rather than flesh and blood. . . . I doubt if that rarefied air will make good red blood and plenty of it. . . . How much better are sound bones and a good digestion in poetry than all the philosophy and transcendentalism in the world!" For Burroughs, as we learn in "The Flight of the Eagle," the essay on Whitman that follows the Emerson critique in Birds and Poets (1877), the "physiological" character of Whitman's writing makes it healthy poetry, as does the poet's "thorough assimilation of the modern sciences, transmuting them into strong poetic nutriment" $(\mathcal{F B}, 3: 229,241)$. American readers, Burroughs argues, need the "assimilative powers" of Whitman's bodily digestion to help "absorb" Emerson's disembodied ideals ( $\mathcal{F B}, 3: 229)$. In contrast to the cerebral transcendentalism of Emerson's Nature, Whitman provides the health of "Nature's stomach."

This quasi-physiological reading of Whitman's "flesh and blood" difference from Emersonian poetics has been common in our criticism. Whitman is "Emerson with a body," as Lewis Hyde has put it: "It was for Whitman to read Emerson's 'Nature' and take it to heart, to feel the soul's tongue move in his breast, an epiphany of animal heat." ${ }^{5}$ Robert K. Martin, echoing both Whitman and Burroughs apparently unawares, expresses gratitude for Whitman's "carnality, after the frigidity and bloodlessness" of Emerson. ${ }^{6}$ More recently, Jay Grossman pursues a substantial rethinking of the Emerson-Whitman relation by contrasting Whitman's material differences from Emerson: poetry as "a form 
of embodied labor" for Whitman versus "the disembodied utterances of Emerson's 'The Poet'."7 However, Whitman's imagined "digestion" of Emerson's books points up a problem with this critical tradition in need of attention. Whitman uses a digestive figure (food into chyle into blood) to mark his material difference from, and rejection of, Emerson's writing; but this same, complex figure for poetry's embodiment, I hypothesize, is assimilated from Emerson's poetics. Whitman can't imagine "eating" Emerson's pages, and yet the very figure suggests that he already has.

Jerome Loving speculates that Whitman's unfair criticism of Emerson, no doubt motivated by Whitman's conspicuous absence from Parnassus (1874), the anthology of poems edited by Emerson, might also be informed by Whitman's declining health-just as Emerson's snub of Whitman might have resulted from Emerson's own decline in memory and mental facility (355). ${ }^{8}$ The physiology of the poets in their later years - ailments that affect Whitman's stomach and Emerson's brain, as it happens - influences the critical judgment of the poetics. ${ }^{9}$ In this essay, however, I am interested in the physiology of digestion within the poetics of both writers-physiology figured as poeticsrather than in the bodies of the writers themselves. I would argue that we have remained somewhat coached by Whitman in this matter of his physiological difference from Emerson-at least to the extent that few critics have interrogated the digestive figure upon which Whitman propagates the criticism of Emerson's "bloodless intellectuality." We have been reiterating Whitman's figuring of poetics as digestion without giving the metaphor-in its relation to Emerson's own writing, or to Whitman's characterization of Emerson's influence-much thought. Moreover, a point I will emphasize in focusing on texts from the later work of these authors in the 1870s, reconstruction years for both, we have yet to investigate sufficiently Whitman's "Emersonianism" (the question of Emerson's influence) at the end, rather than the beginning, of these writers' careers. As such, we have been largely repeating Burroughs's diagnosis that Whitman's physiological poetry reinvigorates, if not replaces, the airy and disembodied intellect of the early Emerson of Nature - Whitman's body and bowels reaching down to earth from the blithe air of Emerson's uplifted, disembodied brain. In restricting physiology to the biology of the aging authors, rather than the biography of their poetics, the critical tendency has been to view the later works of both in terms of an inevitable decline. This view belies a complexity I locate in the digestive figures circulating in and around two neglected yet important works, Whitman's Two Rivulets (1876) and Emerson's "Poetry and Imagination," the opening essay in Letters and Social Aims published in December, 1875. Some measure of that complexity to 
be taken up in this essay could be put this way: Whitman's seemingly simple rejection of Emerson's metaphorical, bloodless "chyle" turns out to be no mere metaphor at all, but a crucial metonymy that Whitman learns from Emerson.

\section{INTELlectual Digestion}

The repetition of the argument regarding the presence of the "stomach" in Whitman and its absence in the cerebral Emerson coalesces around the word "chyle." Both F. O. Matthiessen and Betsy Erkkila quote from Whitman's "permanent chyle" passage, albeit to different ends. For Matthiessen, Whitman's rejection of Emerson's "cold intellectuality" in the name of less "grammatical" speech is betrayed in his own language, "deeply ingrained with the educational habits of a middle-class people." 10 Erkkila cites the same passage to emphasize Whitman's location of language in "democratic culture," of and for the "lives of the American masses," in contrast to Emerson's view of language originating exclusively in nature. ${ }^{11}$ Both critics share, however, the unexamined assumption of Whitman's stomach, neither providing any comment upon, nor context for, the digestive figure implicit in Whitman's criticism and marked in the words "chyle" and "bloodless." This can be said to extend all the way back to Burroughs, who remarks of Emerson's "irremediable deficiency" in terms that should now sound familiar: "In the writing most precious to the race, how little is definition and intellectual formula, and how much is impulse, emotion, will, character, blood, chyle!” ( $\mathcal{F B}, 3: 181)$.

Critics, I understand, have long recognized Whitman's engagement with physiology, his poetic interest in matters of the stomach as well as the heart. Indeed, the word "physiological" is one that Whitman offered late as the "impetus-word" for Leaves of Grass (PW, 2:725, 770). Harold Aspiz reveals the crucial relation between Whitman's poetry and "the physical, physiological body" that he locates in Whitman's "transmutation into poetry of scientific and quasi-scientific medical lore"; one among many sources for this transmutation that Aspiz identifies is Whitman's review of Fowler's Physiology, Animal and Mental in the Brooklyn Daily Eagle in March of $1847 .{ }^{12}$ However, there is a more complicated figuring of physiology marked by "chyle" and its digestive associations that has been overlooked in Whitman criticism, despite our awareness of the physiological impetus of his poetics. This neglect appears despite the fact that the word "chyle" appears eight times in Whitman's published writing, including his criticism of Emerson. More to the point of this essay, this same word "chyle" appears in Emerson's "Poetry and Imagination" along with variations on this figure, what Emerson calls the poet's "intellectual digestion." Whitman and Bur- 
roughs were in attendance for Emerson's lecture "Imagination and Poetry" (a source for the eventual essay) at the Peabody Institute in Baltimore in January 1872 and may well have heard him use this rather un-transcendental, scientific analogy for poetry. Interestingly, in his 1876 critique of Emerson in which he identifies Emerson's deficiency of "chyle," Burroughs refers to the recently published "Poetry and Imagination" as an example of Emerson's overly transcendental and ultimately bloodless "intellectual formula." Burroughs, however, makes no quotation of Emerson's own interest in the figure in that very book. ${ }^{13}$ As a figure for poetry's nutritive absorption and embodiment by readers, two words surely of great importance to Whitman and familiar to his criticism, Whitman's "chyle" and its poetics of digestion mask a more complicated relationship with Emerson's poetics.

In giving more thought to this poetics of digestion in both authors, however, I also mean to complicate and not merely repeat another critical convention in the Emerson-Whitman tradition: the view of Whitman's complete absorption of Emerson's ideals that defines Whitman exclusively in terms of his supposedly "singular identification with Emerson's 'Poet'," as Jay Grossman puts it in his recent de-coupling of "Emerson/ Whitman" (92).${ }^{14}$ As we will see, in both the works of Emerson and Whitman and in the science of physiology they draw upon, absorption and assimilation, prominent terms in discussions of the digestive process, suggest porosity rather than singular or complete identification. As we will also see, digestive "assimilation" offers a paradox of identity through change, of composition by way of decomposition. Digestion, in this sense, is an internal version of the kind of "ceaseless play of counterpart upon counterpart [that] brings constant restoration and vitality" that Whitman, in the opening paragraph of Democratic Vistas, locates in the "perennial health-action of the air we call the weather" $(P W, 2: 362)$. One rhetorical name for such ceaseless play in poetic figures, the name Emerson uses to characterize poetry's natural and porous vitality, is metonymy. This is a further point toward a more complicated assimilation, I would argue, that we have neglected in thinking about Whitman's "Emersonianism." Though Emerson uses and names metonymy as a central condition of poetic imagination in his later work, he continues to be thought of in terms of metaphor-and in contrast to Whitman's own interest in metonymy. However, at the same time, Whitman's own poetics of metonymy is thought to decline in his poetry after the Civil War. As we give more thought to the poetics of digestion in both authors, we necessarily need to give more time to the role of metonymy in that poetics.

In Whitman, metonymy means poetry and physiology are convertible terms. Webster's (1828) defines metonymy (from the Greek for "change of name") as a rhetorical trope in which one word substitutes for 
another based upon a relation between the two; it offers as an example, "We read 'Virgil,' that is, his poems or writings." In reading "Whitman," the body of the poet's book metonymically relates to the body (more specifically, the hand) of the poet; both bodies, physical and textual, stand in proximal relation to the body of the reader-as Whitman likes to remind us - now holding him in hand. Burroughs has this poetics of proximity in mind when he distinguishes Emerson's disembodied transcendentalism from the healthy influence of Whitman's texts - though he doesn't use the word "metonymy" to describe it. ${ }^{15}$ In his study Language and Style in Leaves of Grass, C. Carroll Hollis does use the word, devoting a substantial chapter to metonymy in the poetics of Leaves of Grass. ${ }^{16}$ Drawing upon the linguistic theories of Roman Jakobson among others, Hollis emphasizes that metonymy and metaphor are not merely two among many figures of speech, but rather polarities in the spectrum of expression: from metonymy's context-bound communication by way of contiguity and sequence (something Jakobson associates with prose) to metaphor's context-free symbolism of similarity and simultaneity (associated with poetry). Webster's highlights this contrast in defining metaphor as a similitude or comparison often reduced to a single word, without the signs of comparison or relation present. As Hollis aptly summarizes the theorizing of this difference from twentieth-century perspectives in semiotics, metaphor is symbol while metonymy is sign (icon and index). In contrast to the paradigmatic nature of metaphor, metonymy's syntagmatic signs indicate their contexts, their handling by the author (158-159).

The critical tendency to view Whitman as the embodiment of Emersonian intellect, then, extends to the signifying differences between metonymy and metaphor that Hollis elucidates. Whitman, in this view, materializes by way of metonymy the transparency of Emersonian transcendental metaphor. Just as metonymy, in its emphasis on context, materializes tropes and resists (at the other polarity) the metaphorical potential of language to render context immaterial, so too we might say Whitman materializes Emerson. Ed Folsom envisions the emergence of Whitman's own transcendental poetics along the lines of both inspiration and revision, observing Whitman's attendance at Emerson's 1842 lecture "The Poet" in New York, one in which Emerson declares "All things are symbols" and offers an example that surely must have caught Whitman's ear-"We say of man that he is grass." "While Emerson emphasized the metaphorical nature of these tropes," Folsom argues, "Whitman would eventually learn to push them in metonymic ways, seeing not the 'great difference of aspect' between a man and grass but witnessing instead the literal ways that a man is grass transformed through natural cycles." ${ }^{17}$ Emerson, as Jonathan Bishop would claim, is "the hero of metaphor, the Representative Man of symbolic action"18; 
and Whitman, as Hollis concludes, "is not a great metaphoric poet but is the best metonymic poet in the business" (203). Emersonian metaphor may bring Whitman to a boil, but it is the metonymic condensation from that boiling, the conversion of symbols into the literal, that yields Whitman's poetry.

One problem with this critical view as it relates to Emerson concerns the crucial role that metonymy in fact plays in Emersonian poetics, particularly in his later writings on poetry. This poetics finds its culminating statement in "Poetry and Imagination," where Emerson takes up the familiar perspective of the correspondence of poetry and nature, the poet's recognition of the symbolic nature of all things. However, in elaborating this understanding that "Nature is itself a vast trope," Emerson turns explicitly to the figure of metonymy to explain the poet's perception and recording of the vast and unending trope of Nature. "All thinking is analogizing," Emerson writes, "and 'tis the use of life to learn metonomy [sic]." ${ }^{\prime 9}$ Though that line is quoted often in Emerson criticism, there has been surprisingly little discussion of Emerson's concept of metonymy-in contrast to the presumption of Emerson as the "hero of metaphor." Barbara Packer, a notable exception in this tendency, quotes this line in arguing that Emerson shifts his poetics in the later writings on poetry from the vision of symbolic correspondence and metaphorical fixture located in Nature (where Emerson names Nature a "metaphor of the human mind"), to one of poetry as the metonymic registration of nature's ongoing metamorphosis. "The problem with even the best metaphors," Packer argues, "is that they tend to degenerate into clichés, which is why Emerson recommends metonymy - the trope of association, not of likeness - as a way out of metaphor's petrifying powers." ${ }^{20}$ In the poetics of "Poetry and Imagination," Emerson emphasizes the poetic reading and reporting of nature as the conversion or transformation or assimilation or transfiguration of nature's metonymic associations. As such, Emerson argues that "metonymy" names a convertibility that is already in nature, one that the poet converts or materializes naturally into poetry. "We are advertised that there is nothing to which man is not related; that everything is convertible into every other," Emerson writes of "this metonymy, or seeing the same sense in things so diverse": "The chemistry of this is the chemistry of that," Emerson goes on to say, another way of saying that metonymy, the relation (and conversion) of every "this" to "that," names the very chemistry of nature $(C W, 8: 12)$.

Emerson conceives the chemistry of nature's process as an organic or literal figure for poetic imagination. "Rightly, poetry is organic," Emerson argues further in "Poetry and Imagination" with regard to the poet's "awful nearness to Nature's creations": "Such creation is 
poetry, in the literal sense of the term" ( $C W, 8: 22-23)$. Thoreau makes a similar argument in Walden, moving from his ecstatic observation of thawing sand in early Spring to "the principle of all the operations of Nature": "The very globe continually transcends and translates itself. . . . There is nothing inorganic." It is worth noting that Thoreau also views this organic translation of nature's "living poetry" in physiological and "somewhat excrementitious" terms: "You here see perchance how blood vessels are formed"; "this suggests at least that Nature has some bowels." 21 The language I cite from "Poetry and Imagination" in my first epigraph suggests that Emerson also has those bowels in mind. Emerson figures the organic nature of poetic imagination - both for the writer and for the reader of the poetry - as a form of "intellectual digestion," a process in which the very globe, as Thoreau puts it, continually transcends itself through material translation. Emerson's focus on the poet's conversion of the daily and common life of America into poetry, along with the recognition that it is "slow to find a tongue," recalls "The Poet," the essay published in 1844. I am thinking of the lines that we often imagine Whitman reading and answering in his own tongue: "I look in vain for the poet whom I describe" (CW, 3:21). At the same time, I suspect that many readers of this "intellectual digestion" passage, perhaps even Burroughs, have heard in Emerson's "transubstantiation" of bread into symbols a worn path back to Nature and its metaphors of airy transcendence. To read Emerson's "intellectual digestion" in this way, however, would require us to discount the metonymic emphasis Emerson gives to the poetics of digestion elsewhere in the essay. Moreover, we would have to neglect the ways Emerson himself "transmutes" this poetics, throughout this essay and the various lectures related to it, from his own considerable interest in science. Like Thoreau's, Emerson's nature has some bowels.

This is the same essay, after all, where Emerson says "poetry is science" and most famously, "Poetry is the gai science," on his way to emphasizing the rightly organic nature of poetry. This poetics of science is fundamental to the essay and its metonymic vision of the poet's imagining of the world as an endless series of partial, and thereby poetic, relations $(C W, 8: 20,19) .{ }^{22}$ The writer's transcendental vision of that relation may be based on what Emerson calls "rare elevation," but it is a rarefied air and intellect that feeds continuously upon a raw, physiological engagement with the world. "Now at this rare elevation above his usual sphere, he has come into new circulations, the marrow of the world is in his bones, the opulence of forms begins to pour into his intellect" $(C W, 8: 21)$. Creative expression is built up from the atomic level, in a series of transfigurations and associations that link the materials of the earth to the body to the bowels to the blood to the mind to thought 
and imagination that (re)produces the poetry. "Many transfigurations have befallen them," Emerson writes of the "surface facts of matter" that the intellect acts upon, seeing poetry in its metonymy:

The atoms of the body were once nebulæ, then rock, then loam, then corn, then chyme, then chyle, then blood; and now the beholding and co-energizing mind sees the same refining and ascent to the third, the seventh, or the tenth power of the daily accidents which the senses report, and which make the raw material of knowledge. $(C W, 8: 12)$

This vision of poetic transfiguration is a version of metonymy: each thing is another name for the raw material of everything to which it is related, part and particle, from atom to mind. The "chemistry" of digestion in the midst of this analogy (corn into chyme into chyle into blood), relates to, but also figuratively feeds, the chemistry of knowledge and thought with which the passage (and the process) concludes. One way of saying this is that the thinking Emerson produces in writing the essay and developing its theory of poetry, including its theory of poetry as a metonymy of digestion, is informed by that very process. We only follow the example of Emerson's theory in taking this one step further: the word "metonymy" in this essay is a metonymy for the world and the body that condition it, just as digestive chyme and poetic chimes, like body and mind, stand in material, if not etymological, relation. ${ }^{23}$

In analogizing the process of food becoming nutrient for blood and mind, Emerson transmutes into his poetic theory a physiological understanding of assimilation. For some definition of this digestive register, consider the textbook First Lessons in Physiology by C. L. Hotze, published in 1874 for use in common schools. Digestion is defined as a multi-stage process of "changes wrought upon the food in the body" in three parts: "1. Digestion, or the proper preparation of food in the alimentary canal, so as to fit it for absorption. 2. Assimilation, or the conversion of food into blood and tissue 3. Excretion, or the decomposition of food and its removal from the body." Further reading into the digestive process of absorption and assimilation defines "chyme" as the pulp formed from initial digestion of food in the stomach and "chyle" as the "milky fluid produced by further digestion of chyme in the intestines before it passes as nutrient into the circulation of blood." The 1828 Webster's confirms the prominence of this physiological meaning for assimilation in offering as a definition for the verb "assimilate" the following: "To convert into a like substance; as, food is assimilated by conversion into animal substances, flesh, chyle, blood, etc." In Hotze's physiological text, as with Emerson's metonymy of "many transfigurations," the process of assimilation culminates in thinking. The final lesson of the book is titled "The Mind"; the circulation of food into chyme into chyle into blood nourishes the brain and informs 
the health of the mind and its powers for perception and, ultimately, creative thinking. ${ }^{24}$ "The mind is a finer body," Emerson writes in his essay on Swedenborg in Representative Men, locating imagination in an unending series of nature's iterative relations: "Here in the brain is all the process of alimentation repeated, in the acquiring, comparing, digesting, and assimilating of experience. Here again is the mystery of generation repeated . . . each series punctually repeating every organ and process of the last" ( $C W, 4: 61)$. In Emerson's material relation of brain to body, the mind reiterates its participation in the experience of digestion.

Thus chyle marks the metonymy, and not the metaphor, of Emerson's "intellectual digestion" and every thought and figure it seems to draw to its "tongue." Even circulation-which figures prominently in Emerson's writing for the idea of thought as circular and moving, for nature as incessant metamorphosis - is tinged by this natural poetics of digestion. In his lecture "The Natural Method of Mental Philosophy," from an 1858 series of the same name that included an early version of "Poetry and Imagination," Emerson offers a series of circulations that speak to the way the mind can understand that "there are no finalities in nature," that "Transition, shooting the gulf, becoming somewhat else, is the whole game of nature": "Life is unceasing parturition." After

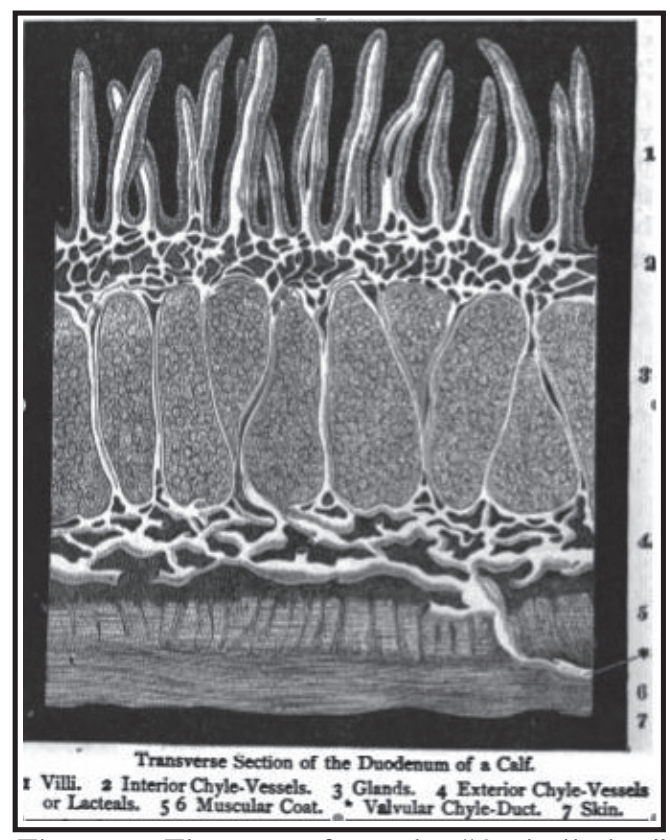

Figure 1. Figure 27 from the "Assimilation" chapter of Hotze, First Lessons in Physiology, 122. pointing to this method of nature found in the circulation of water and of gas, Emerson writes: "The circulation of the blood in the little world of man, food into chyme, chyme into chyle, chyle into blood, hurled from the heart in endless spasm, to rush through the system, carrying nutriment to every organ and every extremity." ${ }^{25}$ Nature may be a metaphor of mind, as Emerson put it in his first publication, but in this later poetics, we see, nature moves through the metonymic processes of assimilation located in the digestive system. One of the figures in Hotze's First Lessons in Physiology, a transverse section of the duodenum of a calf, graphically 
represents the symbolic potential of this organic and natural metonymy that Emerson has in mind (Figure 1). Indeed, imagining this to be another version of Thoreau's poetic and excrementitious sand foliage (if not also an interior view of the cow that crunches Whitman's grass), we could re-word Thoreau to say, "The Maker of this earth but patented digestion" (207). ${ }^{26}$

Emerson's "intellectual digestion" conveys this crucial sense of metonymic circulation in its figure-one where circulation is the relevant name for the way figures circulate in thinking, as in nature. The unceasing metamorphosis and porosity of the figure (and in the figure) makes it liable for misrecognition, as Emerson well knows. "Poetry and Imagination" ends with a discussion of the inevitable misunderstanding of poetry by way of further reference to the poetics of intellectual digestion and circulation. Of "the defects of poets" who have made only "partial ascents to poetry," Emerson writes, "The drop of ichor that tingles in their veins has not yet refined their blood, and cannot lift the whole man to the digestion and function of ichor, - that is, to godlike nature. Time will be when ichor shall be their blood, when what are now glimpses and aspirations shall be the routine of the day" $(C W, 8: 41)$. This is another place, I suspect, where Emerson's poetics seem to slide into metaphors of transcendence. Ichor, as Emerson suggests, is the godlike blood of Greek mythology, a divine replacement of human blood-yet more Emersonian bloodlessness. But Emerson's "digestion and function of ichor" concludes what we have seen to be a rather material focus on the relation between digestion and imagination, between the bowels and the brain, between the poet and the people. Emerson's poet, here, is notably different from the "finer poet" with "finer ear" of Emeron's1842 lecture; no genius above or even among the people, he is the people-a people whose own resistance to poetry "only proves their liking of poetry" and indicates their fitness for becoming poets themselves. ${ }^{27}$ Poetry, Emerson understands, is made of such change. "Perhaps Homer and Milton will be tin pans yet," Emerson writes in arguing that poetry must necessarily be "outgrown" (a line that troubled Burroughs in his criticism of this text): "The poet should rejoice if he has taught us to despise his song; if he has so moved us as to lift us, - to open the eye of the intellect to see farther and better" $(C W$, $8: 13,38)$. Emerson's "ichor" is fed by his vision of an unceasing-and, here, countervailing - circulation he names metonymy. Neglecting that metonymy, we might also neglect the implication that "ichor," in physiological terms, is a mark of decay; the 1913 Webster's lists, after the mythological "ethereal fluid," a secondary definition: "thin, acrid, watery discharge from an ulcer, wound, etc." ${ }^{28}$ Digestion embodies in its organic process such implications of decay. As Emerson suggests, the recognition of imperfection attends any poetic figure that would 
rightly represent the metamorphic nature of things. Swedenborg receives Emerson's criticism in this essay for neglecting this metonymic perspective of poetry and its imaginative use of life - for attempting to freeze the material correspondences of the past into dead metaphors ("dead scurf") of the divine; for Emerson, Swedenborg's digestion of experience belies an artificial perfection. ${ }^{29}$ And though Emerson (to be clear) does not name Whitman in "Poetry and Imagination," he offers in this physiological vision of poetry's metonymic circulation, wounds and all, an organic perspective of interest to Whitman.

\section{INTERIOR ChYLE}

In his 1876 "Preface," first published in the opening of Two Rivulets, the companion volume in the Centennial edition of Leaves of Grass that is presented for the first time as a two-volume set, Whitman begins with a focus on the physiological. However, in contrast to earlier editions in which this "impetus-word" and organizing idea is celebrated as a sign of the poetry's (and its persona's) vitality, here the focus is on illness, specifically Whitman's own:

At the eleventh hour, under grave illness, I gather up the pieces of prose and poetry left over since publishing, a while since, my first and main volume, "Leaves of Grass"-pieces, here, some new, some old-nearly all of them (sombre as many are, making this almost death's book) composed in by-gone atmospheres of perfect health - and preceded by the freshest collection, the little "Two Rivulets," now send them out, embodied in the present melange, partly as my contribution and outpouring to celebrate, in some sort, the feature of the time, the first centennial of our New World nationality - and then as chyle and nutriment to that moral, indissoluble union, equally representing all, and the mother of many coming centennials. ( $P W, 2: 464)$

Whitman calls Two Rivulets a "melange," a word he also uses to forewarn readers of Specimen Days and Collect six years later that his "fragmentary" collection of prose pieces, also left over, are re-composed in a time of illness (after his 1873 paralytic stroke) and in the hope of restoration and recovery. The "melange" communicates not just despite the confusion or "convulsiveness" of Whitman's physio/graphical composition, his body's and his text's condition; the mélange or mixture communicates through it: "let the melange's lackings and wants of connection take care of themselves." Whitman uses the word "convulsiveness" in a note from Memoranda During the War, the text re-printed in Two Rivulets and later absorbed into Specimen Days. The word speaks to this idea of the communicative significance of his condition in this way: "As I have look'd over the proof-sheets of the preceding pages, I have once or twice fear'd that my diary would prove, at best, but a batch of convulsively 
written reminiscences." "Well, be it so," Whitman apologizes but also commands: "They are but parts of the actual distraction, heat, smoke and excitement of those times. The war itself, with the temper of society preceding it, can indeed be best described by that very word convulsiveness." The italics, it should be noted, are Whitman's; the word is a visible specimen of the excitement the text wants to convey $(P W, 1: 1,112) .{ }^{30}$

In Two Rivulets, pieces convulsively written and re-collected are parts of the distraction of illness and pathology — one that Whitman's body shares sympathetically with his poetry and his times. Further on in the "Preface," Whitman worries about living "amid a general malaria of fogs and vapors" and "the morbid facts of American politics" (PW, 2:466-467). This imagery of illness in the body politic reiterates the "morbific matter" of Democratic Vistas - and Whitman's somewhat mordant diagnosis of America's cultural ailments, partly in reaction to Thomas Carlyle's dyspeptic criticism of American democracy. Two Rivulets also absorbs Democratic Vistas into its collection of prose-just as it will be re-absorbed into the Collect portion of Specimen Days and Collect. In this "Preface," however, "Nature's stomach" isn't strong enough to digest the "morbific matter" - at least, not as strong as Whitman's former poetry. "While that volume radiates physiology alone," Whitman adds in a parenthetical reference to "Leaves of Grass,' my former volume," "the present one, though of the like origin in the main, more palpably doubtless shows the pathology which was pretty sure to come in time from the other" ( $P W, 2: 468)$. Toward the end of this "Preface," Whitman returns to the transmutation of "chyle" into his poetics. In fact, much like Burroughs will do, Whitman suggests that this poetics, tinged with the "chyle" of science, is precisely the nutriment that his poetry needs (in its later, pathological condition) and what is needed for America's future readers: "Without being a scientist, I have thoroughly adopted the conclusions of the great savans and experimentalists of our time, and of the last hundred years, and they have interiorly tinged the chyle of all my verse, for purposes beyond" (PW, 2:472). Whitman uses a similar reference to the interiority of "chyle" in "Poetry To-Day in America-Shakspere-The Future," the piece that follows the 1876 "Preface" in Collect, originally published in the North American Review in 1881. There, however, it is clear that Whitman's "chyle" has not been fully absorbed into the poetry of today and still awaits its future. "Am I content, then, that the general interior chyle of our republic should be supplied and nourish'd by wholesale from foreign and antagonistic forces such as these?," Whitman writes rhetorically, referring to the "feudalism" of Hugo and Carlyle and Tennyson, much as he referred to Emerson's “permanent chyle" (PW, 2:478). 
Whitman's argument that his work in Two Rivulets embodies a shift from physiology to pathology seems to motivate two critical perceptions regarding the post-war decline of Whitman's body of work. Noting that Whitman's declining interest in "being the poet of the body" after the Civil War was likely informed by the loss of his own "physical vigor," M. Jimmie Killingsworth takes the argument a step further: "Above all, it was the quirky physiology of nineteenth-century science writing that Whitman left behind when he shifted the emphasis of his own writing after the war." ${ }_{1}$ The presence of "chyle" in Whitman's published work-all coming in the post-war writing from Two Rivulets and after-suggests, of course, that Whitman retains some interest in the physiology of nineteenth-century science writing. There is a difference, however, a change Killingsworth might have in mind: all of those references to "chyle" and its physiological associations, eight by my counting, appear entirely in Whitman's prose. ${ }^{32}$ Whitman's "chyle" is not a figure of physiology in poetry, a way for the poet-persona to chant the body and its health; it is, by and large, a prose figure for poetics as physiology, a way for Whitman to look back on the body of his work and, especially in the 1870 s, look forward, perhaps with greater concern, to its unfinished absorption in his country. This problem of the post-war prose, in relation to the poetry, informs a second critical assertion that Whitman's "chyle" also complicates. Hollis concludes that Whitman's "writing in the metonymic mode" is strongest from 1855 to 1860 and declines significantly after the Civil War. One problem with the later poetry, Hollis suggests, is that Whitman turns his attention away from its "metonymic verve" by becoming distracted by prose (194). Noting as an example the "steady increase" of the figures of metaphorical absence, in contrast to metonymy's figuring of contextual presence, in the 1870 s poetry of "Passage to India" and "Eidólons," Hollis even speculates that a physiological impairment from Whitman's 1873 stroke might have contributed to the shift away from metonymy to metaphor $(171,224)$.

In contrast with these critical perceptions, we can see that Whitman's poetics of digestion retains - indeed, reinforces - the poet's vital interest in metonymy. It does so, however, in shifting to the reflective poetics Whitman produces in his prose, looking backwards and forward, as well as in shifting between poetry and prose. The mélange of Two Rivulets vividly embodies this shifting between poetry and prose in its form; in the first section, prose runs below the poetry, separated by a boundary (a printer's wavy line) suggesting the fluidity operative in the title. In elucidating Whitman's metonymy and its investment in what he calls "contexture," Hollis suggests the linguistic concept of "foregrounding" as one way that metonymic language is turned into poetry $(178,186)$. The most familiar case addressed by Hollis appears 
in "So Long!"- "Camerado, this is no book, / Who touches this touches a man"-in which the deictic "this" emphasizes the metonymic adjacency of the interaction in the very book one is touching, a relation to the book the author has touched and handled. ${ }^{33}$ Whitman's 1876 "Preface," like the opening of Specimen Days, provides similar metonymic foregrounding in its focus on the embodiment of the mélange, on the ways that this writing palpably (able to be touched, handled) reveals the contexts of its ideas and origins - even to the point, as he would claim for his war memoranda, of blood-stains blotching his Civil War notebooks ( $P W, 1: 2)$. This post-war embodiment of work, in its combined physiological/pathological condition of new and old writing, life and death, politics and immortality, sympathizes with, which is also to say, metonymizes, the condition of his life and its times. Indeed, one could argue that what makes Two Rivulets difficult to read is too much, rather than too little, metonymic foregrounding located in the prose. The "agglomerative" and "eruptive" style of Whitman's writing, as Burroughs describes the saturated "presence" of Whitman's "vascular and human" prose included in Two Rivulets, happens here in front of the reader's eyes: prose not only interacts visibly with poetry, but often discourses with itself, moving into footnotes that compete for the reader's attention, necessitating the reader to choose pathways not only across the book but up and down and even beyond its pages $(\mathcal{F B}, 3: 254)$. In the case of one of the poems originally published in Two Rivulets, "Out from Behind This Mask," the reader is sent out into the companion volume by way of a head note: "To Confront My Portrait, illustrating 'the Wound-Dresser,' in Leaves of Grass." ${ }^{34}$ Thus are absent poems and portraits made present, once again, through the power of Whitman's metonymic "this."

Whitman admits that the "varieties and phases" embodied in the Centennial edition, its physiology and pathology, though "ultimately to be considered as One in structure," are "doubtless often paradoxical, contradictory" (PW, 2:764) ${ }^{35}$ Such foregrounding of his work's mixture of different streams or "veins" of thinking extends to Whitman's discussion of the experimental mixture of poetry and prose that characterizes Two Rivulets. "I have not hesitated to embody in, and run through the volume, two altogether distinct veins, or strata," Whitman writes: "Thus, too, the prose and poetic, the dual forms of the present book" (PW, 2:465). Whitman goes on to refer to this duality of form as an "analogy" of his times $(P W, 2: 473)$. The analogical duality of the book is needed for the digestive health of the body politic: "Estimating the American Union as so far, and for some time to come, in its yet formative condition, I bequeath poems and essays as nutriment and influences to help truly assimilate and harden, and especially to furnish 
something toward what the States most need of all, and which seems to me yet quite unsupplied in literature" (PW, 2:469). Two paragraphs later, Whitman deepens the digestive figuring of his own work as a quasi-scientific experiment in poetic nutriment when he refers to the "chyle of all my verse" having been tinged by the "experimentalists of our time" (PW, 2:472).

The poems and essays of Two Rivulets are bequeathed to American readers "as chyle" and "nutriment and influences to help truly assimilate and harden." Whitman's "assimilate" speaks to the assimilation of the digestive process as well as the experimental assimilation of the work that will furnish and feed his readers the nutriment still unsupplied: the mixture or mélange of its composite form. There is, then, metonymic verve in Whitman's later work, evident in this critically neglected assimilation of poetry and prose located in Two Rivulets. While I will not attempt to offer a comprehensive reading of Two Rivulets that can argue for its unalloyed genius, I would suggest that our reconsideration of Whitman's poetics of digestion offers a starting point for addressing the misdiagnosed condition of this book as a sign simply of Whitman's decline. ${ }^{36}$ Whitman bequeaths not "myself to the dirt" but "poems and essays as nutriment" to influence the digestion of American literature in its readers.

Digestive assimilation is, by definition, dynamic and contradictory. The assimilating process of converting food into chyle into chyme into blood, moving from mouth to stomach to intestines before being partly absorbed into the blood stream and partly excreted as waste, carries with it a ceaseless contradiction. In his physiological lesson on digestive assimilation, Hotze addresses this contradiction of organic matter this way: "at every instant of life a quantity of animal tissue is dying, and must at the next instant be replaced. . . . Thus, death and life are intimately associated and dependent upon each other in the living organism" (119). As the prominent New York physiologist Austin Flint emphasizes in The Physiology of Man (1866), digestive "assimilation" is destructively creative: the need for nourishment of new tissue and blood from the digestion of food is created by the "destructive assimilation" constantly going on in the existing or old tissue. ${ }^{37}$ The body needs nourishment from the digestion of food because it is already in the process of digesting itself. The body contains within itself its own "morbific matter"; decomposition is fundamental to the organic composition of life. Emerson will assimilate this organic paradox from nature into a poetics of reproducibility in his late essay "Quotation and Originality," one of the pieces included in Letters and Social Aims. He concludes his focus on what he names (twice) the "assimilating power" of originality and its contradictory dependence on quotation in just these terms: "The 
divine gift is ever the instant life, which receives, and uses, and creates, and can well bury the old in the omnipotency with which Nature decomposes all her harvest for recomposition" ( $C W, 8: 107)$. Indeed, as the text Outlines of Physiology (1868) asserts in its concluding section on "Death and Decay," since life depends on change in tissue composition, death is when decomposition stops rather than starts. ${ }^{38}$

"Destructive assimilation" is the body's own compost-poetics of decomposition. This understanding illuminates the kind of "ceaseless play of contradiction upon contradiction" that characterizes health and restoration in Democratic Vistas - a health often found lacking in the writing of that very work, as in Two Rivulets. Edmund Gosse's review of Two Rivulets in the Academy critically dismisses the work for the limitations of Whitman's "theory of poetic composition" and his failure to do the "constructive" work of a poet. Gosse asserts, by way of Shelley, that "the mere lazy observation of the current facts of nature" does not constitute poetry, "any more than food or even chyle is in itself blood." 39 Gosse, it should be noted, does not cite Whitman's own reference to poetic chyle in the book. Whitman's invocation of a more complicated poetics of digestion in the experimental composition of Trwo Rivulets suggests to me that we need to give more attention to the decomposition of this book going on in its interiors, informing its poetics. These interiors are the locations in Whitman's prose, before and literally beneath the poetry, where Whitman foregrounds the nutritional need for the absorption and assimilation of the kind of poetry, presumably his, needed in America but not yet supplied.

In Democratic Vistas, Whitman writes toward this unwritten future, claiming that the very word democracy, surely one of his own key words, has yet to be defined or enacted (PW, 2:393). In Two Rivulets, the poetics of the prose, also calling for an as-yet-unfulfilled poetry, is thus set in tension with the very poetry included. Drawing upon lessons from Whitman's war memoranda and his poetics of the "interior" space of the hospitals, Robert Leigh Davis insightfully re-reads the odd mélange of prose in Democratic Vistas, its intertextual "din of disputation," as Whitman's successful argument against "the myth of the self-contained text," a rejection of "the elitist myth of a writer detached from contexts, gazing down on the world like an aloof God." "I I locate a similar disputation in the distracting, intertextual presences of Two Rivulets and its contrasting "veins" of poetry and prose. Indeed, in one of those veins, the note "New Poetry-California, Mississippi, Texas" (later to be incorporated into "Ventures, On an Old Theme"), Whitman argues not only that "the time has arrived to essentially break down the barriers of form between prose and poetry," but more surprisingly that prose, "that other medium of expression, more flexible, more eligible," may 
be the truer medium necessary for the "Muse of the Prairies" ( $P W$, 2:519-520). In Specimen Days, recounting his western journey, Whitman envisions this poetics of the prairies in a familiar figure: "Yes, I think the chyle of not only poetry and painting, but oratory, and even the metaphysics and music fit for the New World, before being finally assimilated, need first and feeding visits here" ( $P W, 1: 214)$. In his review of Two Rivulets, Gosse argues that poetry is distinct from prosaic facts just as chyle is distinct from food and blood; in doing so, he misses the point that Whitman uses that very word as a figure for dissolving such distinctions.

To see this poetics of decomposition at work, consider the poem already cited, "Out from Behind This Mask." As I have suggested, the poem shares in the book's metonymic foregrounding of the poet's body of writing - “confronting” both a poem and a portrait (W. J. Linton's woodcut engraving of George Potter's 1871 photograph of Whitman) printed in the 1876 companion Leaves. The poetry, however, seems largely metaphorical - to such an extent that one might include it with "Passage to India" and "Eidólons" in Hollis's listing of Whitman's metonymic decline: the metaphorical "bending, rough-cut Mask" of the face is elaborated in a series of grand metaphors including "This glaze of God's serenest, purest sky, / This film of Satan's seething pit, / This heart's geography's map" (TR, $24 ; L G, 382)$. The face is a metaphorical map of the heart, another curtain of the body that masks what is going on in the interiors, behind the scenes. Masked in the interior of this poem, however, is Whitman's more familiar metonymy. Reading down the page, in the prose below the first section of the poem, Whitman carries over his discussion of "the main sustenance for highest separate Personality" begun in "Nationality-(And Yet)" on the previous page. Whitman argues that America needs the conception of a nationality that fuses individuality with "the idea and fact of AMERICAN Totality": "We need this conviction of Nationality as a faith, to be absorb'd in the blood and belief of the people everywhere" (TR, 23-24; $P W, 2: 512-513)$. The poetry above, the head and face of the book, as it were, invites contemplation in what Hollis identifies as metaphor's static posture: we gaze on the "glaze" of the poem's figures. The prose below, in the stomach and bowels, as it were, of Whitman's poetics, is a miscellaneous remainder (it will become the first "Notes Left Over" in Specimen Days and Collect, immediately preceding "Emerson's Books (The Shadows of Them)") as well as a reminder: the absorption of this poetry "as chyle and nutriment" to fiber the blood of New World nationality remains in the infinitive (to be), unfinished, in process. Several pages prior to this, Whitman identifies the digestive process he has in mind in a prose section, "Thoughts for the Centennial," that 
runs below the poem "Eidólons." Writing of the "spiritual-esthetic attributes" that are needed for the evolution of the American mind but not yet present, Whitman asserts, "They will gradually enter into the chyle of sociology and literature. They will finally make the blood and brawn of the best American individualities of both sexes-and thus, with them, to a certainty, (through these very processes of to-day,) dominate the New World" (TR, 20; PW, 2:530).

Above that line, in the penultimate stanza of "Eidólons," we read "Thy Body permanent, / The Body lurking there within thy Body" (TR, $20 ; L G, 8)$. Where Hollis and others might find this poetic "Body" too metaphorical in its absence from the body of Whitman's book, too far removed from the metonymic verve of the earlier poetry, we might reconsider these lines by way of the digestive process that lurks in the prose of this page, as in the body. In the physiological terms he invokes, Whitman's nutriment and influence of poetry requires a continuing process of "destructive assimilation." I read such creative tension in "Out From Behind This Mask" in the metonymy that complicates the metaphors of the poem, lurking within its metaphorics of the body. "This condensation of the Universe . . . / These burin'd eyes, flashing to you, to pass to future time" $(T R, 24 ; L G, 382)$. Here the face becomes the metonymic mask of the Universe, condensing, rather than substituting, all that touches it. The word "condensation" figures association rather than likeness, contiguity rather than similarity; it is a convertible term for metonymy. ${ }^{41}$ This metonymy of condensation illuminates the contextual conditions of Whitman's "Mask": the actual portrait to which he refers, located in the other volume. The "burin'd eyes" metonymize the reproduction of that portrait, cut with a "burin," the basic tool of engraving. And when the poem turns in its closing section to a parenthetical reference to this volume we have been holding- "A Traveler of thoughts and years - of peace and war, / Of youth long sped, and middle age declining, / (As the first volume of a tale perused and laid away, and this the second ... . )"-we are reminded that Whitman, despite his declining age, is still up to his metonymic tricks $(T R, 25 ; L G, 382)$. The poet's words and figures portray the man condensed in, and contiguous with, this poetry. This condensation - this composition through the conversion of matter, through decomposition - confronts the reader as much as the poet. Both reader and writer look back and forward in the moment, a convulsive and creative opposition: "Lingering a moment, here and now, to You I opposite turn" (TR, 25; $L G, 382) .{ }^{42}$

This metonymic, creative opposition through the act of reading a book exemplifies the sort of reader-response poetics that Whitman calls for at the end of Democratic Vistas. "Books are to be call'd for, and supplied, on the assumption that the process of reading is not a half- 
sleep, but, in highest sense, an exercise, a gymnast's struggle," Whitman writes of the reader's role in constructing the text of the poem: "Not the book needs so much to be the complete thing, but the reader of the book does. That were to make a nation of supple and athletic minds, well-train'd, intuitive, used to depend on themselves, not on a few coteries of writers" ( $P W, 2: 424-425)$. In his focus on the disputational poetics of Democratic Vistas, Robert Leigh Davis concludes, by way of this same passage, that Whitman confronts his readers with a "cultural pedagogy" that challenges readers to become more resistant and intellectually self-reliant. As Davis suggests, Whitman's “assumption" about "the process of reading" absorbs a pedagogy of gymnastic training and self-improvement prominent in Whitman's time, one in which physiological health and poetic growth, bodies and books, are interwoven (551). ${ }^{43}$ And of course, Whitman's foregrounding of the book and its "process of reading" reminds us that metonymy's relation of parts toward an unwritten whole factors prominently in Whitman's curriculum.

In the end, this paradox of poetic incompletion and pedagogical resistance is also part of the lesson Whitman learns-so he tells us-from Emerson's school. In the conclusion of "Emerson's Books (The Shadows of Them)," Whitman complicates his own rejection of Emerson's bloodless and intellectual "chyle," offered only paragraphs earlier, when he identifies in Emerson's thought a sort of Whitmanian pedagogy of resistant, athletic reading. "The best part of Emersonianism is, it breeds the giant that destroys itself." Whitman concludes: "Who wants to be any man's mere follower? . . . No teacher ever taught, that has so provided for his pupil's setting up independently-no truer evolutionist" ( $P W, 2: 517-518)$. Whitman might well have written (to use, but also to contradict, the language from earlier in the piece) that no truer digestion exists than in Emerson's example. In other words, Whitman assimilates Emerson's paradoxical teachings on the digestive, "assimilative power" of the poet in the process of setting up his own paradoxical judgment. Whitman asserts this idea more directly in a passage from the original article, omitted from the later publication in Specimen Days and Collect, as he concludes, "It remains to be distinctly avowed by me that Emerson's books form the tallest and finest growth yet of the literature of the New World," after explaining the Emersonian teachings informing his earlier criticism:

The foregoing assumptions on Emerson and his books may seem-perhaps areparadoxical; but, as before intimated, is not every first-class artist, himself, and are not all real works of art, themselves, paradoxical? and is not the world itself so? As also intimated in the beginning, I have written my criticism in the unflinching spirit of the man's own inner teachings. ( $P W, 2: 768$ ) 
Whitman's rejection of his "Master" may be unfair as criticism of Emerson in his later years, but it is accurate, we see, in its pedagogical implications. Whitman is coaching us in this late criticism in the paradoxical ways that Emerson has coached him, learning or assuming or assimilating Emerson's own lessons in assimilative anti-mentoring. ${ }^{4}$ There can be no permanence to the absorption of inner chyle, and no complete rejection of its influence either. Though I can only leave this as a speculative suggestion, perhaps too much in Whitman's spirit, one might find a similar lesson in Emerson's apparent rejection of Whitman in the 1870s: purged from Parnassus, the example of Whitman's intellectual stomach is absorbed, nevertheless, into the digestive, metonymic theory of "Poetry and Imagination" and its interests in the reader's part in completing the book of poetry. ${ }^{45}$ Whether or not we read Emerson's late poetics as Whitmanian in that way, the poetics of digestion evident in Whitman's greeting of Emerson at the end of his career suggests a way to understand the complications of the "inner teachings" circulating within the body of work of both authors and, so both would have it, in the flesh and blood of their readers.

\section{Washington College}

\section{NOTES}

1 Walt Whitman, Prose Works, 1892, ed. Floyd Stovall (New York: New York University Press, 1964), 2:517. Hereafter, $P W$.

2 Jerome Loving, Walt Whitman: The Song of Himself (Berkeley: University of California Press, 1999), 395.

3 Orson Fowler, Physiology, Animal and Mental: Applied to the Preservation and Restoration of Health of Body and Power of Mind (1847, rpt. New York: Fowlers and Wells, 1851), 147.

4 John Burroughs, The Writings of fohn Burroughs (Boston: Houghton Mifflin, 1904), 3:179, 193, 196. Hereafter, $\mathcal{F} B$. Burroughs's criticism of Emerson included in Birds and Poets is first published in two parts in The Galaxy in 1876. Loving refers to Whitman's coaching of Burroughs, suggesting that the "essays pertained as much to Whitman as they did to Emerson" (360). Whitman publishes an earlier and briefer criticism of Emerson's "shadows" in "A Christmas Garland, in Prose and Verse" in the New York Daily Graphic in 1874: "I am disposed to think (picking out spots against the sun) that his constitutional distrust and doubt - almost finical in their nicety-have been too much for him - have not perhaps stopped him short of first-class genius, but have veiled it" (PW, 2:759).

5 Lewis Hyde, The Gift: Creativity and the Artist in the Modern World (New York: Vintage, 2007), 220.

6 Robert K. Martin, The Homosexual Tradition in American Poetry (Iowa City: University of Iowa Press, 1998), 92. 
7 Jay Grossman, Reconstituting the American Renaissance: Emerson, Whitman, and the Politics of Representation (Durham: Duke University Press, 2003), 110-111. Len Gougeon cites both Martin and Grossman in his summary of this tendency to distinguish Whitman from Emerson by disembodying Emerson. He also suggests that it has worked in reverse as well, focusing on the ways Oliver Wendell Holmes seeks to separate Emerson's idealism from Whitman's sensualism. I am informed by Gougeon's argument that Emerson's transcendentalism is more complicated in its considerable interest in the body and not just the soul; see Len Gougeon, "Emerson, Whitman, and Eros," Walt Whitman Quarterly Review 23 (Winter 2006), 126-146.

8 In "Emerson's Books" Whitman doubts "if Emerson really knows or feels what Poetry is at its highest," and offers for evidence his liking the "verbal polish" of "Waller's 'Go, lovely rose,' or Lovelace's line 'to Lucasta'” (PW, 2:517). Both of those poems are included in Emerson's Parnassus.

9 In an 1876 letter to Rossetti published in Collect, Whitman refers to his recently published set of Leaves and Two Rivulets and writes of his own physiological condition: "My paralysis does not lift . . . I still have this baffling, obstinate, apparently chronic affection of the stomachic apparatus and liver: yet I get out of doors...digestion tolerable-spirits unflagging" (PW, 2:510). For an overview of Emerson's failing memory and its role in the work of the 1870s, particularly Letters and Social Aims, see Ronald A. Bosco, "Historical Introduction," Letters and Social Aims, vol. 8, Collected Works of Ralph Waldo Emerson, ed. Ronald A. Bosco, Glen M. Johnson, Joel Myerson (Cambridge: Harvard University Press, 2010).

10 F.O. Matthiessen, American Renaissance: Art and Expression in the Age of Emerson and Whitman (New York: Oxford University Press, 1941), 532.

11 Betsy Erkkila, Whitman the Political Poet (New York: Oxford University Press, 1989), 85.

12 Harold Aspiz, Walt Whitman and the Body Beautiful (Urbana: University of I1linois Press, 1980), x, 114.

13 In a letter to his mother on January 5, 1872, Whitman observes that he attended Emerson's lecture with Burroughs and was not interested. In a follow-up comment on Emerson's recent lecturing in his letter to Edward Dowden on January 18, Whitman figures this disinterest in Emerson as a form of ingestion: "He maintains the same attitude-draws on the same themes-as twenty-five years ago. It all seems to me quite attenuated (the first drawing of a good pot of tea, you know, and Emerson's was the heavenly herb itself-but what must one say to a second, and even third or fourth infusion?)"; Walt Whitman, The Correspondence, ed. Edwin Haviland Miller (New York: New York University Press, 1961-1977), 2:150, 155. Bosco indicates that Emerson delivered "Imagination and Poetry" at Baltimore's Peabody Institute on January 2, 1872, with Burroughs and Whitman in attendance ("Historical Introduction," cxxix).

14 Though I share Grossman's interest in reconsidering the conventional singularity of Whitman's identification with Emerson's "Poet," my key point of departure from his approach is to shift the focus toward the later work, away from the question of emergence. It might be noted that Grossman, oddly, does not analyze or at all refer to Whitman's criticism "Emerson's Books (The Shadows of Them)."

15 In a late piece on Emerson, "Flies in Amber," written after the publication of Emerson's journals in the early twentieth century, Burroughs quotes Emerson's reference to "metonymy" from "Poetry and Imagination," though here it is to argue that such 
metonymy is a notable fault in Emerson: "One of Emerson's faults as a writer arose from his fierce hunger for analogy. 'I would rather have a good symbol of my thought,' he confesses, 'than the suffrage of Kant or of Plato.' 'All thinking is analogizing, and it is the use of life to learn metonymy.' His passion for analogy betrays him here and there in his Journals" (The Last Harvest [Cambridge: The Riverside Press, 1922], 92).

16 C. Carroll Hollis, Language and Style in Leaves of Grass (Baton Rouge: Louisiana State University Press, 1983).

17 Ed Folsom, "Transcendental Poetics: Emerson, Higginson, and the Rise of Whitman and Dickinson," The Oxford Handbook of Transcendentalism, ed. Joel Myerson, Sandra Harbert Petrulionis, and Laura Dassow Walls (New York: Oxford University Press, 2010), 271.

18 Jonathan Bishop, Emerson on the Soul (Cambridge: Harvard University Press, 1964), 119.

19 Ralph Waldo Emerson, The Collected Works of Ralph Waldo Emerson, ed. Alfred R. Ferguson et al. (Cambridge: Harvard University Press, 1971- ), 8:7-8. Hereafter, $C W$.

20 Barbara Packer, "Response to Elisa New's 'Where the Meanings Are,"” Religion and Literature 38 (Spring 2006), 29. See also Packer's "Ralph Waldo Emerson," in Columbia Literary History of the United States, ed. Emory Elliott (New York: Columbia University Press, 1988), 390-391. Branka Arsic addresses the importance of Emerson's metonymy in the "Appendix" to her book On Leaving: A Reading in Emerson (Cambridge: Harvard University Press, 2010). Emerson's reference to the "metaphor of the human mind" is from $C W, 1: 21$.

21 Henry David Thoreau, Walden (1854), ed. William Rossi (New York: W.W. Norton, 2008), 206-207.

22 My use of the term "poetics of science" is informed by Laura Dassow Walls, Emerson's Life in Science: The Culture of Truth (Ithaca: Cornell University Press, 2003).

23 Elsewhere in the essay, Emerson (though he doesn't use the chyme/chime pun), does suggest that rhyme and rhythm in poetry are organic in a physiological sense, "derived from the human pulse." The editors of the recently published Letters and Social Aims note Edward Waldo Emerson's suggestion that Emerson's materializing of poetry in this regard relates to Oliver Wendell Holmes's 1875 essay on the topic, "The Physiology of Versification" ( $C W, 8: 25,208)$.

24 C. L. Hotze, First Lessons in Physiology (St. Louis: Central Publishing, 1874), 106,166 . We could point to Whitman as well for this specific register of assimilation in terms of digestion. In Democratic Vistas he writes: "To our model, a clear-blooded, strong-fibred physique, is indispensable; the questions of food, drink, air, exercise, assimilation, digestion, can never be intermitted" ( $P W, 2: 397)$.

25 Emerson, The Later Lectures of Ralph Waldo Emerson: 1843-1871, ed. Ronald A. Bosco and Joel Myerson (Athens: University of Georgia Press, 2001), 2:92, 97.

26 Thoreau writes, "Thus it seemed that this one hillside illustrated the principle of all the operations of Nature. The Maker of this earth but patented a leaf" (Walden, 207).

27 Emerson, "The Poet," The Selected Lectures of Ralph Waldo Emerson, ed. Ronald A. Bosco and Joel Myerson (Athens: University of Georgia Press, 2005), 92. 
28 The 1828 Webster's lists only the physiological, not the mythological, definition: "Sanious matter flowing from an ulcer."

29 Emerson precedes the "intellectual digestion" passage by offering Swedenborg as an example of poetic genius that fails to convert the "circumstance of to-day" into poetry: "'Tis boyish in Swedenborg to cumber himself with the dead scurf of Hebrew antiquity, as if the Divine creative energy had fainted in his own century. American life storms about us daily and is slow to find a tongue" ( $C W, 8: 18)$.

30 I explore further Whitman's logic of the specimen and its photographic resonances in the final chapter of my book, Mediating American Autobiography: Photography in Emerson, Thoreau, Douglass, and Whitman (Columbia: University of Missouri Press, 2008).

31 M. Jimmie Killingsworth, "Human Body," Walt Whitman: An Encyclopedia (New York: Garland Publishing, 1998), 286. Text available at the Walt Whitman Archive (www.whitmanarchive.org).

32 The eight appearances of "chyle" in Whitman's published writing: "Origins of Attempted Secession" (Memoranda), 1876 Preface (Two Rivulets, twice), "Poetry To-day in America" (Collect), "Foundation Stages-Then Others" (originally in Two Rivulets), "Art Features" (Specimen Days), "Emerson's Books (The Shadows of Them)" (Collect), "Old Poets" (Good-Bye My Fancy).

33 Walt Whitman, Leaves of Grass: Comprehensive Reader's Edition, ed. Harold W. Blodgett and Sculley Bradley (New York: New York University Press, 1965), 505. Hereafter, $L G$.

34 Walt Whitman, Two Rivulets (Camden, 1876), 24. Hereafter, TR. A full-text scan of this edition is available in Google Books. This head note becomes the subtitle, "(To Confront a Portrait.)," in the 1881 edition of Leaves of Grass (381). When citing poetry from Two Rivulets, I include original page numbers along with citations from the comprehensive edition of Leaves of Grass since the poetry's presence on the page, and its proximity to the prose, is a key to my argument.

35 This comes from a paragraph later omitted from the re-publication of the 1876 "Preface" in Specimen Days and Collect.

36 I have in mind the argument Ed Folsom made over a decade ago, challenging critics to give more thought to the "generally ignored" Two Rivulets and "toward a more inclusive investigation of Whitman's overall project, one that included prose works, poetic supplements to Leaves, and experimental works that challenged generic distinctions: the 1876 Centennial matched volumes, with their roiling mixture of texts, can be read as the culminating moment of Whitman's career instead of a sign of decline." "Walt Whitman," Prospects for the Study of American Literature: A Guide for Scholars, ed. Richard Kopley (New York: New York University Press, 1997), 138-139. Frances E. Keuling-Stout takes up Folsom's challenge in arguing against the book as an illustration of decline in her entry on Two Rivulets in Walt Whitman: An Encyclopedia available at the Walt Whitman Archive (www.whitmanarchive.org).

37 Austin Flint, The Physiology of Man (New York: D. Appleton and Company, 1866), 44 .

38 John Marshall with Francis G. Smith, Outlines of Physiology, human and comparative (Philadelphia: Henry Lea, 1868), 999. 
39 Edmund Gosse, "Walt Whitman's New Book," The Academy 9 (June 24, 1876), 602-603. Full text available at the Walt Whitman Archive (www.whitmanarchive.org).

40 Robert Leigh Davis, "Democratic Vistas," in A Companion to Walt Whitman, ed. Donald D. Kummings (West Sussex: John Wiley and Sons, 2009), 547.

41 In his theoretical overview of metonymy vs. metaphor, by way of Jakobson and others, Hollis lists "dream condensation" as metonymic in contrast to the metaphoric "dream symbolism"(158).

42 I draw upon Ed Folsom's cogent reading of "Out From Behind This Mask" as a complex example of Whitman's photographic poetics; Folsom argues that the "metonymic trick" (quoting Hollis) of this poem exemplifies Whitman's "complex strategy for forcing the reader into an athletic struggle with his poems, challenging the reader to be active not passive, to enter into the creative act, to bring the poem to life, not to sit back and wait for the author-ity to pour meaning into the vessel-reader" (Folsom, Walt Whitman's Native Representations [New York: Cambridge University Press, 1994], 140).

43 Whitman's interest in the pedagogy of gymnastic training is taken up by Brett Barney, "Nineteenth-century Popular Culture," in A Companion to Walt Whitman, ed. Donald Kummings, 236-238.

44 Lawrence Buell, Emerson (Cambridge: Harvard University Press, 2003), 288. Buell's final chapter is "Emerson as Anti-Mentor" and begins with reference to Whitman's "best part of Emersonianism."

45 Though I have left this suggestive speculation unexplored in this article, I would point for some potential grounding to the critical insights of Ronald A. Bosco regarding Emerson's editing of Parnassus and the poetic theory of "Poetry and Imagination" that intertwines with the volume of poems. Bosco argues that Parnassus is informed by Emerson's theory, developed in "Poetry and Imagination," that the reader must share in the poetic process by becoming a poet. However, this sharing comes (as ever with Emerson) by way of resistance: "for Emerson a text has no integrity of its own, only an integrity that is read, defined, or imposed on it by the reader." One implication is that Parnassus is deliberately presented to "teach the reader "to despise his song,", Bosco writes, quoting from "Poetry and Imagination" (Bosco, "Poetry for the World of Readers' and 'Poetry for Bards Proper': Poetic Theory and Textual Integrity in Emerson's Parnassus," Studies in the American Renaissance, ed. Joel Myerson (Charlottesville: University Press of Virginia, 1989), 297. Whether or not Whitman takes his exclusion from Parnassus as a provocation for the self-reliant reader, it is clear from Bosco that Emerson is conceiving his own sort of "gymnastic" poetics. 